\title{
Indoor Air Quality (IAQ) Performance in Refurbished Projects: A Case Study of Two Private Schools in Selangor
}

\author{
E.M.A Zawawi ${ }^{1, *}$, A.Z Azaiz ${ }^{1}$, S.N Kamaruzzaman ${ }^{2}$, N.M. Ishak ${ }^{1}$, and F.N.M, Yussof \\ ${ }^{1}$ Centre of Studies for Construction, Faculty of Architecture, Planning and Surveying, University Technology MARA, Selangor, \\ Malaysia \\ ${ }^{2}$ Department of Building Surveying, Faculty of Built Environment, University of Malaya
}

\begin{abstract}
This study discusses the Indoor Air Quality (IAQ) in two refurbished private schools in Shah Alam, Selangor. The level of IAQ may affect the comfort, health and well-being of the occupants of the building. Lack of monitoring IAQ in a school may affect the academic performance of the children. The objectives of the research are to observe the ventilation system used in the selected school and the comfort of the occupants; to measure the IAQ; and finally to provide an improvement plan for better air quality. The result shows that the IAQ level of both schools was average, so both were classified as safe for occupation. It is anticipated that this study will benefit the school owners in making sure that their school buildings are conducive to teaching and learning.
\end{abstract}

\section{Introduction}

There is increasing concern about the effect of Indoor Air Quality (IAQ) on human health. The parameters involved in determining a healthy IAQ include the effect of volatile organic compounds (VOC), microbial contaminants including mould and bacteria, gases including carbon dioxide $\left(\mathrm{CO}_{2}\right)$, radon $(\mathrm{Rn})$ and carbon monoxide (CO), and particulate matter (PM) such as water, in addition to temperature, ventilation and humidity. Chua et al. [2] proved that poor IAQ may result from inadequate ventilation, contaminated air and extreme temperatures. Lack of monitoring these parameters may affect the performance of the building and its occupants. The national requirement for minimum airflow rate, $30 \mathrm{~m}^{3} /$ hour, is dependent on the number of residents or the room's purpose. In addition, Er et al. [3] found that a low level of IAQ could lead to sick building syndrome (SBS), a term used to express the negative experience of a building's occupants. In serious cases SBS can lead to uncomfortable conditions such inability to concentrate when spending time in the building, drowsiness and headache. Er et al. [3] also stated that the ventilation system and building materials could be a basis of internal air microbial sources.

Another important physical component of IAQ is thermal comfort that is temperature and relative humidity (RH), which can cause the growth of airborne microbial infection. Chua et al. [2] found that $\mathrm{CO}_{2}, \mathrm{CO}$, $\mathrm{PM}, \mathrm{VOC}$, and indoor microorganisms are closely related risk factors which may result in respiratory problems among school children. A study by Nur Aida et al. [5] found that children in pre-school in urban areas were particularly vulnerable to indoor air particles, compared to those from rural areas. This might be because of the poor IAQ they experience. It is also important to recognise the association between wellness and students' learning ability and the importance of providing a healthy learning environment for children [2]. Fang et al. [4] indicated the importance of indoor air temperature and humidity on perceived air quality and SBS symptoms. In practice, the required ventilation rate for comfort and health should no longer be independent of indoor air temperature and humidity. In other words, people with medical conditions such as allergies, connective tissue disorders and asthma are at even greater risk than the general population if living in these conditions for a long time.

In November 2008, Marzuki et al. [5] conducted a study on IAQ. A total of three primary schools were chosen as a case study. The study aimed to evaluate the ventilation rates, levels of PM and air quality differences between schools. All parameters were measured in each of three randomly selected classrooms, during school hours and a questionnaire distributed and completed at the same time.

\subsection{Refurbished Buildings}

Refurbishment involves a process of rehabilitation, modernisation, renovation, improvement, adaptation, additions, repairs, renewal and retrofitting carried out on existing buildings, but excluding maintenance and cleaning work [9]. In refurbished buildings the user is normally expected to have enhanced indoor environmental quality with performance similar to their expectations of a new building. Prihatmanti and Bahauddin (2014) [8] stated that an effective way to 
increase sustainability is by re-use adjustment. This can be done by reducing the use of materials, air pollution, carbon emissions and the use of transport and energy. Changing the function of an existing building can also reduce costs, compared to demolishing and rebuilding. However, problems have been found related to closed environmental quality including IAQ. IAQ is now the main issue for debate in the built environment because of its effect on human health. Therefore, it is very important to the building owner to conduct an IAQ assessment to ensure the good quality of air in the building, hence providing a healthy building.

Recent studies have found that Malaysians tend to spend most of their working hours indoors, which may expose them to dangerous indoor air pollution from $\mathrm{CO}$, $\mathrm{CO}_{2}$, formaldehyde $\left(\mathrm{H}-\mathrm{CHO}\right.$ or $\left.\mathrm{CH}_{2} \mathrm{O}\right)$ and other VOCs. This condition may be worse in air-conditioned buildings because there is less air exchange in the building. Furthermore, modern buildings are not arranged to prevent the spread of diseases. Regardless of whether the building is old, new or refurbished, it is important to make sure that the IAQ requirement is effectively the same and driven by the building's use and social factors.

\section{Methodology}

Indoor Air Quality measurement was conducted to collect data on the levels of various indoor and ambient air constituents. Two private refurbished schools in Shah Alam Selangor (Sekolah Rendah Integrasi Pintar Bukit Jelutong and Sekolah Sri Pintar Seksyen 7) were chosen for the study. Sampling was conducted simultaneously in three classrooms in each school. Both schools are air-conditioned and have ceiling fans. Parameters including temperature, $\mathrm{RH}$ and $\mathrm{CO}_{2}$ were measured. Table 1 shows the details of the schools and their different characteristics.

Table 1. Comparison of the characteristics of School A and School B

\begin{tabular}{|c|c|c|}
\hline & SCHOOL 'A' & SCHOOL 'B' \\
\hline Location & $\begin{array}{c}\text { Taman } \\
\text { Greenhill, } \\
\text { Seksyen U10, } \\
\text { Shah Alam, } \\
\text { Selangor } \\
\text { Darul Ehsan, } \\
\text { Malaysia } \\
\\
\text { Located in a } \\
\text { commercial } \\
\text { building in a } \\
\text { residential } \\
\text { area but near a } \\
\text { main road }\end{array}$ & $\begin{array}{l}\text { No 22-24, Jalan Zirkon } \\
\text { F7/F, Seksyen } 7 \text { Shah } \\
\text { Alam, Selangor Darul } \\
\text { Ehsan, Malaysia } \bullet \\
\text { Located in a commercial } \\
\text { building in a residential } \\
\text { area but far away from a } \\
\text { road or highway }\end{array}$ \\
\hline Ventilation & $\begin{array}{l}\text { Split unit air- } \\
\text { conditioning } \\
\text { system }\end{array}$ & $\begin{array}{l}\text { Split unit air-conditioning } \\
\text { system and ceiling fan }\end{array}$ \\
\hline Building & 2 Storey & 3 Storey \\
\hline
\end{tabular}

\begin{tabular}{|c|c|c|}
\hline Height & & \\
\hline $\begin{array}{c}\text { No of } \\
\text { occupants }\end{array}$ & Teachers: 12 & Teachers:15 \\
& Students: 120 & Students: 200 \\
\hline
\end{tabular}

The IAQ measurements followed the guidelines from the Industry Code of Practice on Indoor Air Quality (COP-IAQ), Department of Occupational Safety and Health, Malaysia (DOSHM), 2010. RH, volatile $\mathrm{CO}_{2}$, air velocity, temperature and $\mathrm{CO}_{2}$. These data were limited by the availability of the two types of measurement equipment used: Delta Ohm Model 32.2 for temperature, air velocity and $\mathrm{RH}$; and $\mathrm{CO}_{2}$ Sensor for concentrations of $\mathrm{CO}_{2}$ and VOCs.

\section{Data Collection and Analysis}

Data were collected from three classrooms in each school, in May-June 2018, with the parameters listed above. In every case, readings were taken every 30 minutes from 10.30 a.m. until 16.00 p.m. The data were then grouped to be analysed using Microsoft Excel.

\subsection{Data analysis}

Figures 1 and 2 present the temperature data for the three classrooms in School A and School B respectively. Figure 1 show that the temperature reading in the third classroom of School A at 10.30 a.m. was lower than in the other two classrooms. At this time of day, the third classroom is empty because the 38 students have an Islamic class in the Prayer Room. The highest temperature reading was in the second classroom at 12.30 p.m., during the lunch break; sunlight had penetrated into the room through the tophung windows of this room.

Figure 2 indicates no significant difference between the temperature readings in all three rooms, except that the reading for the first classroom was lowest at 14.30 p.m. when students left the class for the Prayer Room without switching off the air conditioning system. In School B, the number of students in the first classroom is the lowest compared to the second and third classrooms, at 14, 22 and 20 respectively, and its temperature reading is similarly the lowest throughout the day.

Figures 3 and 4 illustrate the RH readings between three classrooms in both schools, showing no significant different between the two schools. The lowest RH reading in both was between 15.30 p.m. and 16.00 p.m., because the air conditioning systems were switched off once the students had left the school. The air conditioning system plays a prominent role in providing right $\mathrm{RH}$ level in the building, as shown by the very high readings during the learning activities in class. 


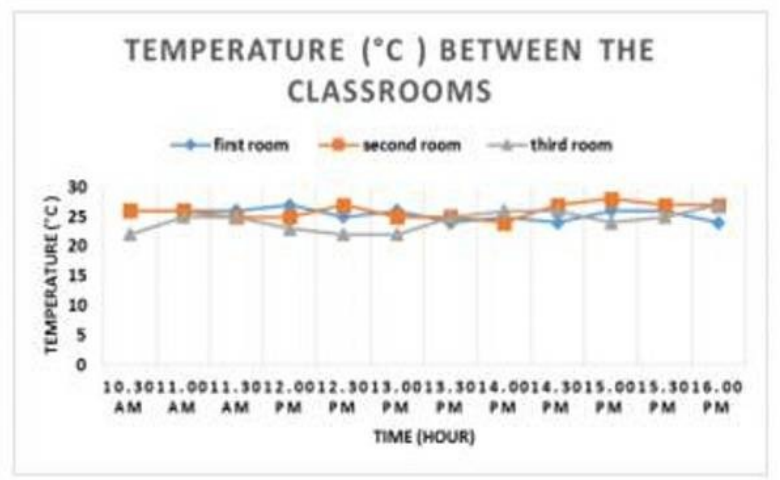

Fig 1. Temperature between the classrooms at School A

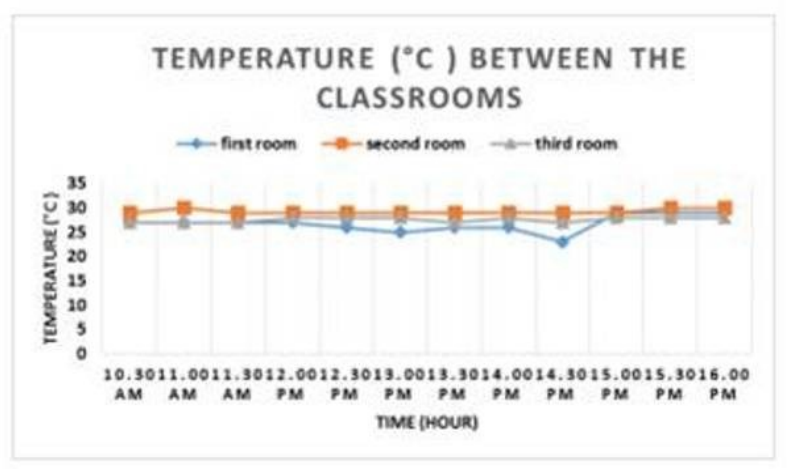

Fig 2. Temperature between the classrooms at School B

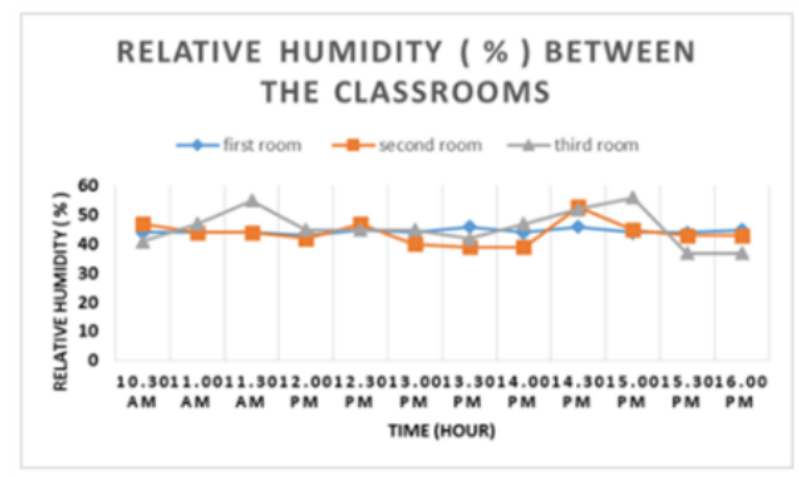

Fig 3. Relative Humidity (RH) between the classrooms at School A.

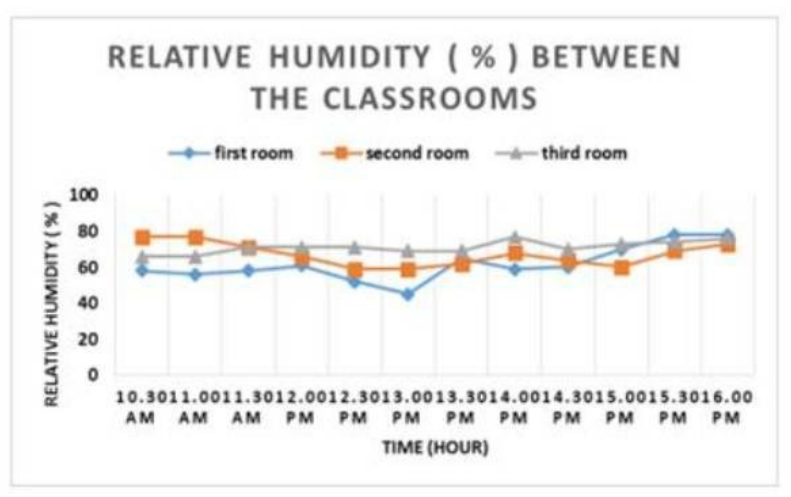

Fig 4. Relative Humidity $(\mathrm{RH})$ between the classrooms at School B

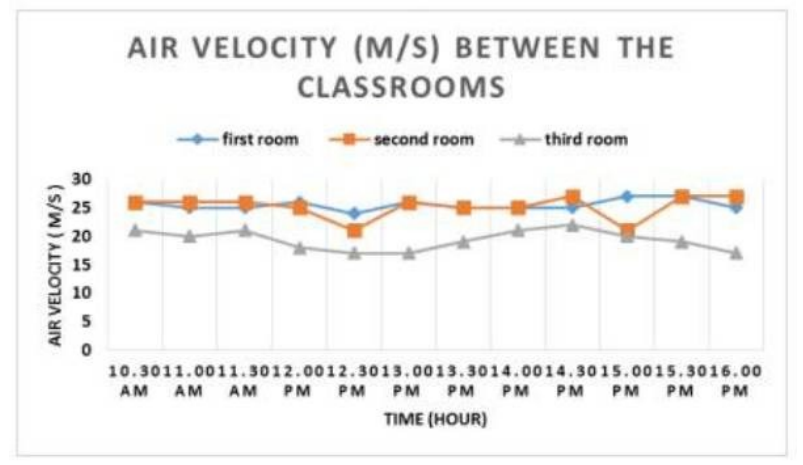

Fig 5. Air velocity between the classrooms in School A

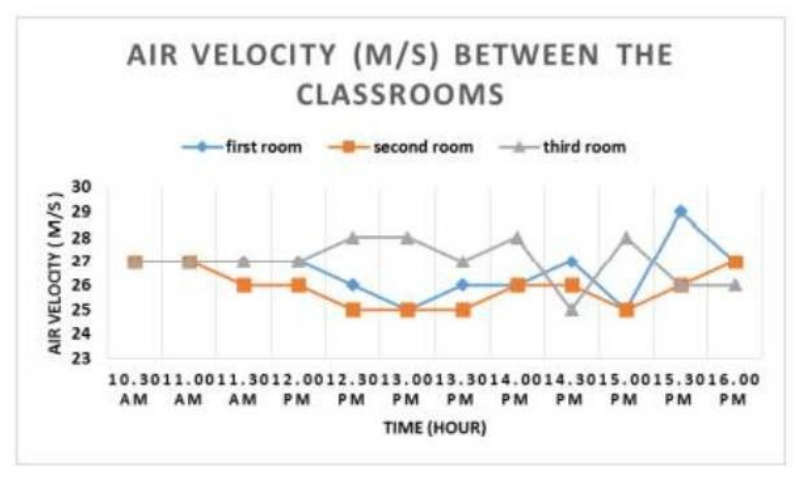

Fig 6. Air velocity between the classrooms in School B

Figures 5 and 6 illustrate the air velocity readings in School A and School B respectively. In School A the first classroom had the lowest reading of the three classrooms during most of the day, and the third classroom the highest. The third classroom was the smallest and was located on the ground floor, while the other two were located on the upper floor.

Figure 6 shows that the highest reading for air velocity was in the first classroom at 15.30 p.m., when the ceiling fan had been switched on. The air velocity decreased after 16.00 p.m. when the air-conditioning system and ceiling fan had been switched off at the end of the class.

Figures 7 and 8.shows the $\mathrm{CO}_{2}$ concentrations. In School A, the concentration was lowest at all times in the third classroom, which was occupied by the lowest number of students.

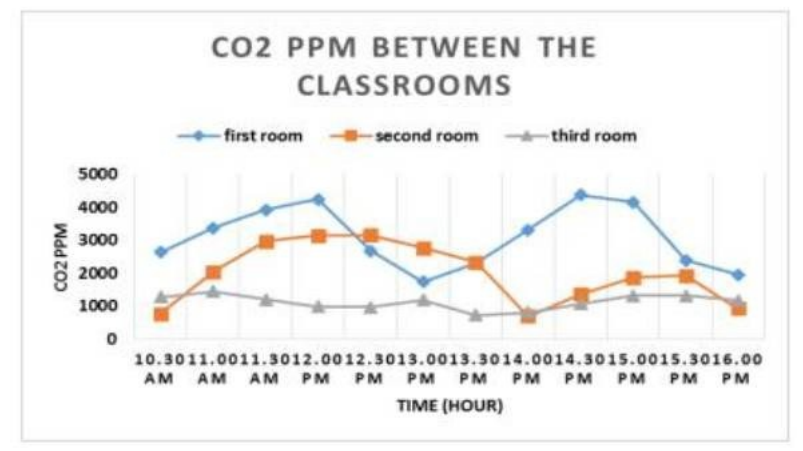

Fig 7. Carbon Dioxide $\left(\mathrm{CO}_{2}\right)$ concentration between the classrooms in School A. 


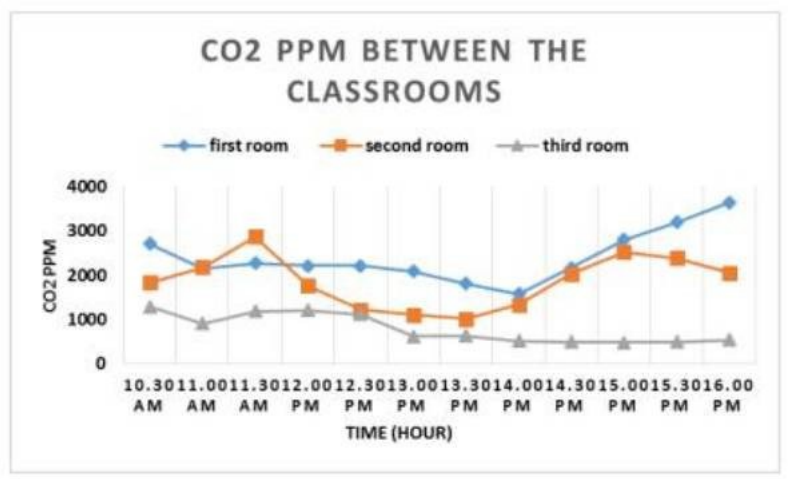

Fig 8. Carbon Dioxide $\left(\mathrm{CO}_{2}\right)$ concentration between the classrooms in School B

In School B, the $\mathrm{CO}_{2}$ reading was low at 10.30 a.m. in every classroom as this was recess and the room was is empty. At other times, the first classroom had the highest concentration even though it had the fewest students; the size of this room was also the smallest. Also, the location of the first classroom was on the ground floor, while the second was on the first floor and the third on the second floor. This corresponds to the $\mathrm{CO}_{2}$ readings in the classrooms.

Figures 9 and 10 show the VOC concentration in both schools. In all three classrooms in both schools, it settled at zero.

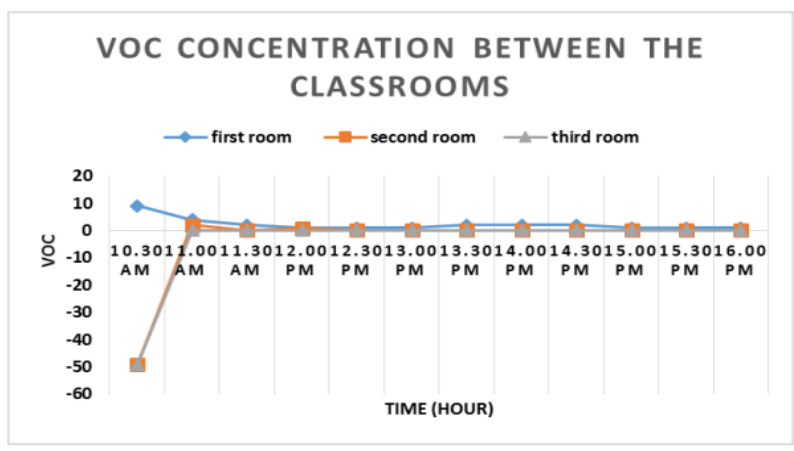

Fig 9. VOC concentration between the classrooms in School A

VOC CONCENTRATION BETWEEN THE CLASSROOMS

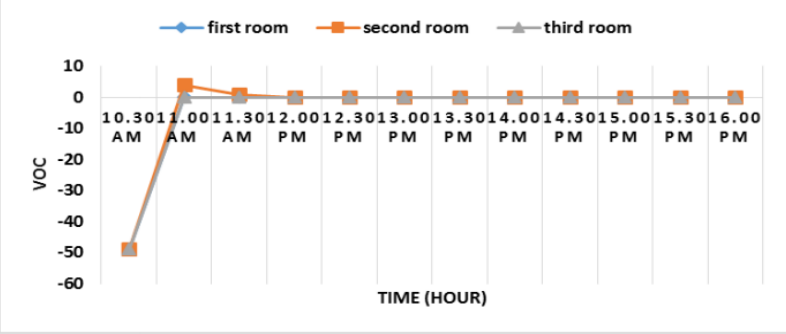

Fig 10. VOC concentration between the classrooms in School B

\subsection{Comparison of IAQ parameters between the Selected Schools and Standards}

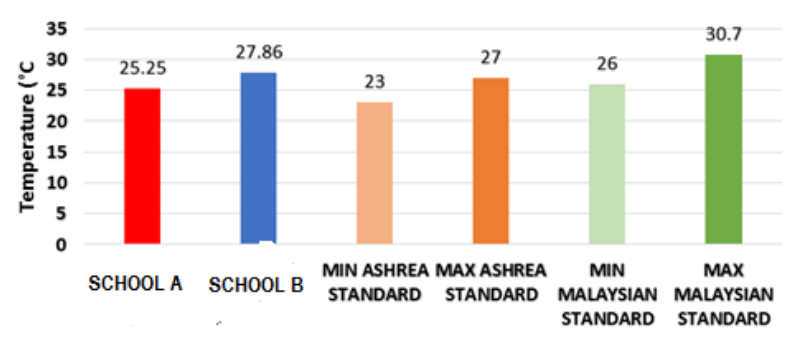

Fig 11. Temperature between both schools against ASHRAE \& Malaysian Standard

Figure 11 shows the average temperature readings in School A and School B compared with the ASHRAE and Malaysian Standard. The average temperature in School A was $25.25^{\circ} \mathrm{C}$ and in School B $27.86^{\circ} \mathrm{C}$. School A's lower indoor temperature range was because it had larger rooms and fewer students. According to the ASHRAE Standard 55-1992, acceptable heat comfort is within the range $23^{\circ} \mathrm{C}$ to $27^{\circ} \mathrm{C}$, so School $\mathrm{B}$ was above the upper limit. As Malaysia is a tropical country, warm and humid, indoor classroom temperatures tend to be higher, at $26^{\circ} \mathrm{C}$ to $30.7^{\circ} \mathrm{C}$ [5], than in the standard ASHRAE environment.

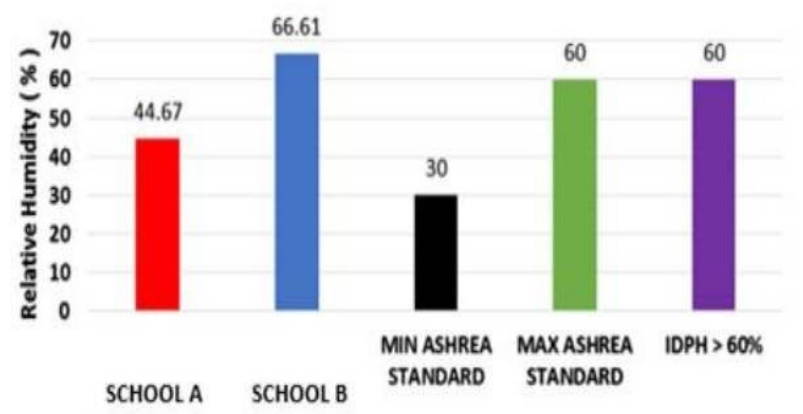

Fig 12. Relative Humidity between the two schools against ASHRAE \& IDPH Standard

Figure 12 shows the average $\mathrm{RH}$ readings compared with the ASHRAE and Illinois Department of Public Health Guidelines for IAQ (IDPH) standards. School A's average relative humidity is below $60 \%$ and is lower than School B's; both schools are fitted with air ventilation systems but School B has more students in smaller rooms. According to IDPH, the best RH for a comfortable stay is over $60 \%$, while ASHRAE's optimum values are between $30 \%$ and $60 \%$. As Malaysia is a tropical wet country, the IDPH figure was used as a benchmark. 


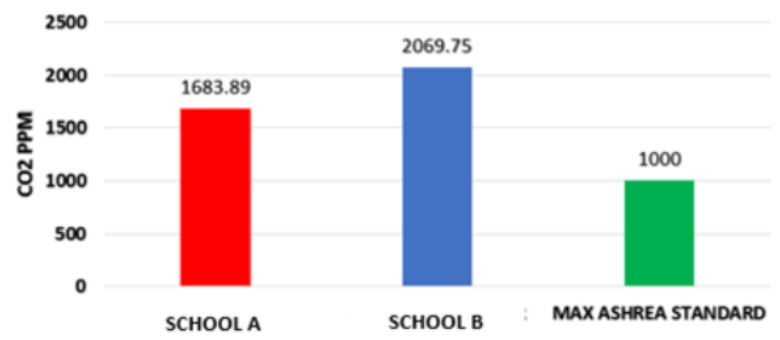

Fig 13. Carbon Dioxide $\left(\mathrm{CO}_{2}\right)$ concentration between the two schools against ASHRAE Standard

Figure 13 shows the average $\mathrm{CO}_{2}$ concentration at School A and School B against the ASHRAE Standard, indicating that both have a higher concentration than the maximum or $1000 \mathrm{ppm}$ recommended by the Department of Safety and Health (DOSH, 2005), and ASHRAE (2001) [1]. The highest concentration for the schools is $1683.89 \mathrm{ppm}$ in an empty air-conditioned classroom and an average of $2069.75 \mathrm{ppm}$ when students have classes.

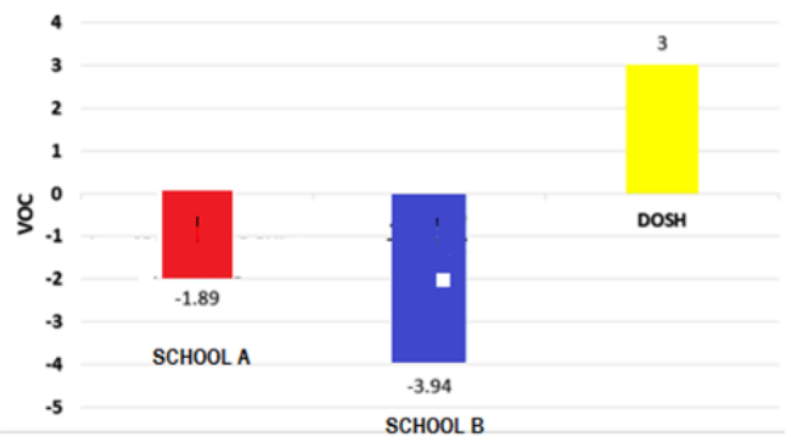

Fig 14. Volatile Organic Compound (VOC) between the two schools against DOSH Standard

Figure 14 illustrates the average VOC concentration at both schools against the DOSH recommended maximum of $3.00 \mathrm{ppm}$. The VOC levels for School A and School B are within -1.89 to -3.94 , indicating zero VOC concentration. Hence both schools meet the DOSH requirements for safe occupancy.

\section{Conclusions}

In conclusion, the result determined the level of IAQ in both schools as average, although the installation of exhaust fans in all classrooms which are occupied all the time is recommended. This is especially the case for rooms with equipment such as computers and photocopiers, in order to reduce heat and odour. It is also recommended that the school staff operate all exhaust fans, air conditioning and mechanical ventilation systems, throughout the school day. They are advised not to switch off the mechanical ventilation systems during short periods of non-occupancy such as break time. This method could reduce the amount of energy used in building. In order to prevent dust accumulation, school owners are advised to schedule preventive maintenance plans that consist of cleaning all the filters for exhaust fans and air conditioning units. It is very important to make sure that all doors are closed for proper operation of air conditioning systems and to maintain comfort. It is anticipated that this study will benefit the schools' owners in providing a conducive indoor environment for teaching and learning activities.

This paper is funded by Research Entity Initiative Grant, 600IRMI/REI 5/3 (008/2018) Universiti Teknologi Mara.

\section{References}

1. ASHRAE Standard 62-2001. Indoor Air Quality A Guide to Understanding, (1), pp40, (2001).

2. P. C. Chua, J., Jalaludin, T. R. Hamedon, \& N. M. Adam, Indoor Air Quality Assessment and Lung Functions among Children in Preschool at Selangor, Malaysia. Advances in Environmental Biology, 9(9), pp1-9, (2015).

3. C. M. Er, N. M. Sunar, A. M. Leman, N. Othman, Q. Emparan, U. K. Parjo, N. A. Ideris, The Evaluation of Indoor Microbial Air Quality in Two New Commissioning Higher Educational Buildings in Johor, Malaysia. Applied Mechanics and Materials, pp773-774, (2015).

4. L. Fang, D.P Wyon, G. Clausen, P.O. Fanger, Impact of indoor air temperature and humidity in an office on perceived air quality, SBS symptoms and performance. Clinical Trial, Research Support, Non-U.S. Gov't, (2004).

5. I. Hussein, \& M. H. A. Rahman, Field study on thermal comfort in Malaysia. Available at; https://pure.uniten.edu.my /en/publications/ fieldstudy-on-thermal-comfort-in-malaysia, (2009).

6. I. Marzuki, N. Zafirah, M. Sofian, A. M. Abdullah, Indoor Air Quality in Selected Samples of Environment Asia, pp.103-108. https://doi.org/10.14456/ ea.2010.48, (2010).

7. A. A. N. Aida, J. Jalaludin, A. B. Suhaili, Indoor Air Pollutants Exposure and the Respiratory Inflammation (FeNO) among Preschool children in Hulu Langat, Selangor. Advances in Environmental Biology, 8 (15), (2014)

8. R. Prihatmanti, \& A. Bahauddin, Indoor air quality in adaptively reused heritage buildings at a UNESCO world Heritage site, Penang, Malaysia. Journal of Construction in Developing Countries, 19(1), pp69-91, (2014).

9. I. Rahmat, and A.S. Ali, The involvement of key participants in the production of project plans and the planning performance of refurbishment projects. Journal of Building Appraisal, 5(3), pp273-288,

(2010). 
10. Technical Paper 2, Indoor Environmental Quality in Refurbishment, Available at:http://seedengr.com/documents/Technical\%20P aper\%20on\%20Indoor\%20environmental\%20qual ity\%20in\%20refurbishment.pdf, (2018)

11. M. Telejko, \& E. Zander-Świercz, Attempt to Improve Indoor Air Quality in Kindergartens. Procedia Engineering, 161, pp1704-1709. https://doi.org/10.1016/j.proeng.2016.08.649, (2016). 